\title{
Educational Game Snakes and Ladders Toward Children Social Development Pre-School Aged in Kindergarten
}

\author{
Suyami $^{1 *}$, Arlina Dhian Sulistyowati ${ }^{1}$, Fitriana Noor Khayati ${ }^{1}$, Riski Fetra Rahayu ${ }^{1}$ \\ ${ }^{1}$ Department of Nursing, Stikes Muhammadiyah Klaten, Klaten, Indonesia \\ *Corresponding author. Email: suyami@ stikesmukla.ac.id
}

\begin{abstract}
Currently, many children spending more time to watch the television and playing the gadget which might influence their social development. Social development could be developed optimally through several playing activities, such as education game snakes and ladders. This study aimed to determine the effect of educational game snakes and ladders to social development of pre-school aged children. This study used one group pretest - post-test design. This study was held at Sukorejo Wedi Kindergarten. A total 36 population of preschool aged children (60-72 months) and sample as many as 16 children. The sampling technique used purposive sampling with participants received intervention educational game snakes and ladders. The data before and after intervention were collected using questionnaires. Then, the data analysed with Wilcoxon signed-rank test. Our findings showed the average pre-test and post-test score on social development was 7.31 and 9.06 , respectively. The results of statistical test showed 0.000 . There is influence of educational game snakes and ladders towards social development of preschool aged children.
\end{abstract}

Keywords: children, game snakes and ladders, study

\section{INTRODUCTION}

Groups of children who are in the process of growth and development that are unique, meaning that they have physical growth and development patterns (fine motor and gross motor coordination skills), intelligence (thinking, creativity, emotional intelligence, spiritual intelligence), socio-emotional (attitude and behaviour and religion), and language and communication that are specific in accordance with the level of growth and development that is being through by children, therefore stimulation from caregivers is needed [1]. The stimulation can be given by parents by many interventions.

Children in Indonesia are tops the most hours of television viewing among countries in ASEAN, with the average time spent reach 5 hours per day. The habit of watching television can reduce children's social interaction so that it can interfere with children's adaptation and friendship, and can make children shy because they are isolated from their relationships with peers [2]. Problems when watching television children often forget time, sometimes because of addiction children can all day watching television and can affect playing time with children as they are [3].

Indonesia is the $6^{\text {th }}$ country internet user in the world after Japan. There is increase between 2016 to 2018 , with 102.3 million in 2016, 112.6 million in 2017, and 123 million in 2018. The negative impacts of using gadgets on children such as children tend to be individualistic and difficult to get along [4]. The incidence of developmental disorders is still relatively high around the world, namely in the United Stated of America ranged from 12-16\%, 24\%, in Thailand,
$22 \%$ in Argentina and 13-18\% in Indonesia. The 2010 Indonesian Health Demographic Survey (IDHS), the number of early childhood (0- 72 months) was 26.09 million, 13.5 millions of them aged between $0-36$ months and children aged 40-72 months reaching 12.6 million children. Children who experience developmental delays based on the number of children are around $14.08 \%$ [5]. Child development can be grown optimally through playing activities. Through playing activities, children's thinking ability is stimulated to utilize their emotional, social and physical aspects. Educational game that can be given to children aged 60-72 months is playing snakes and ladders in order to stimulate various fields such as socialization, cooperation, cognitive, sportsmanship, motor functions. In snakes and ladders games, children are required to wait their turn to play so that they can increase patience and in terms of socializing children.

The previous research showed that Team Games Tournaments type of Cooperative Learning Model using snakes and ladders media had an impact to social attitude of students in learning. The state of the art is the educative games is needed to stimulate pre-school aged children's development. Based on the results of a preliminary study at Sukorejo Wedi Kindergarten on Wednesday, March 21, 2018 , data was obtained that the number of students was 76 children. The results of the interview with the teacher at Sukorejo Wedi Kindergarten found data that children in terms of interacting with teachers are good even though interacting only with the same friends. The child is still shy when invited to meet 7 of 10 children, marked with a soft voice and lowered his head down. At Sukorejo Wedi Kindergarten has never been given a snake ladder game for 
Table 3 The mean score of social development pretest and posttest respondents educative game of snakes and ladders at ABA Sukorejo Wedi Kindergarten 2018 ( $\mathrm{n}=$ 16)

\section{METHOD}

Used quays-experiment method with one group pre-test post-test design without control. Population in this study was preschool children who attend ABA Sukorejo Wedi Kindergarten. The sample required for each game was 4 respondents. We divide into 4 groups, so we need as many as 16 respondents. The inclusion criteria were children with 60-72 months old, children that had social development score 7-8 and children that could count from one until six. This research was conducted in Mei 2018. This research used snakes and ladders toys and pre-screening developmental questionnaire which was called KPSP in Indonesia. This questionnaire consisted 10 questions. The intervention was held 3 times in a week during 30 minutes.

\section{RESULTS AND DISCUSSION}

\subsection{Results}

Based on Table 1, it shows that the average age of respondents is between $64.50 \pm 3.38$ months.

Table 1 Average age of respondents social development at Aba Sukorejo Wedi Kindergarten in 2018

\begin{tabular}{|cccc|}
\hline Respondents & \multicolumn{3}{c|}{ Age } \\
\cline { 2 - 4 } age (months) & Min-Max & Mean & SD \\
\hline & $58-73$ & 64.5 & 3.38 \\
\hline
\end{tabular}

Meanwhile, based on Table 2, it shows that the gender of respondents was equal, 8 males and 8 females.

Table 2 Frequency distribution of Gender respondents social development at ABA Sukorejo Wedi Kindergarten in $2018(\mathrm{n}=16)$

\begin{tabular}{|lcc|}
\hline \multirow{2}{*}{ Gender } & \multicolumn{2}{c|}{ Distribution } \\
\cline { 2 - 3 } & $\boldsymbol{f}$ & $\boldsymbol{\%}$ \\
\hline Male & 8 & 50 \\
Female & 8 & 50 \\
Total & 16 & 100 \\
\hline
\end{tabular}

Based on Table 3, it shows the pre-test score of social development with lowest score was 7 and the highest score was 8 (average score $7.31 \pm 0.479$ ). The lowest post-test score of social development was 7 and the highest score was 10 (average score $9.06 \pm 0.772$ ).

\begin{tabular}{|ccccc|}
\hline $\begin{array}{c}\text { Social } \\
\text { Development } \\
\text { Score }\end{array}$ & Min & Max & Mean & SD \\
\cline { 2 - 5 } Pretest & 7 & 8 & 7.31 & 0.479 \\
Postest & 7 & 10 & 9.06 & 0.772 \\
\hline
\end{tabular}

Based on Table 4, the normality test of social development with Shapiro-Wilk found that $\mathrm{p}$ value of pre-test $=0,000(\alpha$ $<0.05)$ and $\mathrm{p}$ value post-test $=0.001(\alpha<0.05)$, so that the data was declared not normally distributed, then bivariate analysis should use Wilcoxon signed rank test.

Table 4 Normality of social development data at ABA Sukorejo Wedi Kindergarten in $2018(\mathrm{n}=16)$

\begin{tabular}{|lccc|}
\hline \multirow{2}{*}{ Score } & \multicolumn{3}{c|}{ Social Development } \\
\cline { 2 - 4 } & Statistic & df & Sig \\
\hline Pretest & 0.591 & 16 & 0.000 \\
Postest & 0.769 & 16 & 9.06 \\
\hline
\end{tabular}

Table 5 Scores social development before and after an educational game snakes and ladders at ABA Sukorejo Wedi Kindergarten in $2018(\mathrm{n}=16)$

\begin{tabular}{|lcccc|}
\hline $\begin{array}{c}\text { Social } \\
\text { Development } \\
\text { Score }\end{array}$ & $\boldsymbol{n}$ & Mean & SD & p value \\
\cline { 2 - 5 } & 16 & 7.31 & 0.479 & 0.000 \\
\hline Pretest & 16 & 9.06 & 0.772 & \\
Postest & & & &
\end{tabular}

Table 5 showed the result of bivariate test that used Wilcoxon signed rank test which obtained $\mathrm{p}$ value $=0,000$ $(\alpha<0.05)$, so that there was the influence of snakes and ladders educational games on children social development.

\subsection{Discussion}

\subsubsection{Characteristics of respondents}

\subsubsection{Age}

The results of the study in table 1 note that the age of the youngest respondent is 58 months and the oldest is 73 months. The average age of the respondent is 64.50 months. Age is one of the factors that can describe one's maturity both physically, psychologically and socially, so that it helps someone in his knowledge. Increasing age, the level of maturity and strength of a person will be more mature in thinking and working. So that it is expected at the age of preschool then at that age the child has reached maximum maturity to think and doing activities compared to the age below [6]. Motoric development of children aged 60-72 months is very rapid, especially gross motoric. The gross motoric development of children is closely related to 
physical development and self-confidence. If at the age of 60-72 months the child cannot do gross motoric skills, then the child has experienced delays. Therefore motor stimulation must be developed because children who get directed and regular stimulation will develop faster than children who are not / less get stimulation [7].

\subsubsection{Gender}

The results of the study in table 2 show that the sex of male experiencing social development problems is as many as 8 people or $50 \%$ and female 8 people or $50 \%$. That high-scale testosterone exposure increased the risk of speech delay in male with high blood testosterone levels who would experience a delay of 2 or 3 times greater than female. In this study it was found that $61.5 \%$ of the respondents were boys and the remaining $38.5 \%$ were girls [8]. The research results Ngumboro [9], suspecting the high number of child respondents who were diagnosed suspect their social development might be influenced by the characteristics of the respondent's gender and the level of education of the mother who were overall known to come from a low educational background. The research results Ernawati [10] show in general children have normal patterns of growth and development, and this is the result of the interaction of many factors that influence children's growth and development. One of them is female sex faster than male, during puberty women generally grow more than men and then after passing puberty male will be faster.

\subsubsection{Aspects of social development for preschool children before being given an educational game on snakes and ladders}

The factors that influence whether or not a child's social development can be influenced by various things, one of which is lack of stimulation. This theory is in line with Wulandari's research that aspects of preschool child development before being given stimulation of educative game tools are categorized as doubtful because those preschoolers have never before received sufficient stimulation from both the school and parents [11].

Before being given associative play to the development of social personal pre-schoolers in Dharma Wanita Kindergarten, Tlogomas Malang, it turns out that children's development is not in accordance with the age in children. This mismatch is usually influenced by factors of parents who do not pay much attention to their children in socializing with their friends and even their families. Parents do not provide stimulus to their children so that children do not know what to do when meeting friends and do not know how to interact with friends. Children with inappropriate social development will not want to play with their friends [12].

\subsubsection{Aspects of social development of preschool children after being given an educational snake ladder game at Aba Sukorejo Wedi Kindergarten}

Based on table 4 shows that the score of social development after being given educational games is a score of 7 as many as 1 respondent $(6.2 \%)$, score 8 as many as 1 respondent $(6.2 \%)$, score 9 as many as 10 respondents $(62.5 \%)$ and scores 10 as many as 4 respondents $(25 \%)$. After being given the treatment of educational games $68 \%$ of respondents had normal development, but there were still those who had dubious developments. Variation in the developmental aspects of respondents can be caused by one of them, stimulation obtained both in the environment and outside the environment [5]. That given the stimulation of educational game tools can provide significant changes. The results of the study showed that after playing with educational tools the development aspect increased so that it encouraged parents or teachers to prevent delays in children [13]. Based on the research of Ngumboro [9] showing that after receiving play therapy the role of social development in suspect children decreased to $13.3 \%$. This is in accordance with the theory of, which is a game tool that can optimize children's development, according to age and level of development and is useful for physical development, development of cognitive development language and social development [11].

\subsubsection{Effect of educative game of snakes and ladders to the social development of preschool age children}

The results of the Wilcoxon analysis on respondents obtained $\mathrm{p}$ value $=0,000<\alpha=0.05$ so it was concluded that there was the influence of snake ladder educational games on social development at preschool age at Sukorejo Wedi Kindergarten.

Educative games an activity that is very pleasant and can be an educational method or tool that is educational, which is useful for improving language skills, thinking, and associating with the environment [14]. Educational and creative games are game tools that can optimize children's development according to age and the level of development and is useful for physical development, language development, cognitive development and social development [11].

Indicate a change in aspects of preschool child development between before and after being given an educational game tool, where aspects of preschool children's development after being given stimulation of educational games in the normal category. Changes aspects of these developments for the stimulation of educational games very effective tool to stimulate children's development, since in general the child's age is still in the stage play [5].

That most parents provide good educational games, so it can be concluded that the use of educational games can affect children's development. Providing stimulation of educational tools that are not good due to education, parents 
with university education have a better ability to understand the selection of educational games [1].

The influence of tool educational games (puzzle) on cognitive development at age 5-6 years. Learning by using educational tools (puzzles) properly and regularly cognitive development can develop well and quickly because it is helped by games as a means of learning children [15]. That the influence of role-playing therapy to the social development in preschool children. Play therapy is effective in increasing social development in children because games make children look at each other actively [9]. That stimulation can affect gross motoric development in 6-12 months infants. The cause of gross motor development delay in infants aged 6-12 months is the lack of providing motoric stimulation. No stimulation is given when the child has enough time to do gross motor movements, such as standing, lying down, lifting can cause gross motor development to be disrupted.

The stimulation administration can affect the development of socialization. Social personal development is strongly influenced by the environment and the interaction between children and parents or other adults. Child development will be optimal if social interaction suits the needs of children at various stages of development [16]. That snakes and ladders educational games are made with the aim of developing social emotional aspects, one of which is self-confidence and a positive body image [17].

The learning model type Teams Games Tournament (TGT) with a ladder snake media has an influence on the social level students [18]. The results same of Pramesti [19], snake ladder game can improve the language development of preschoolers. The successful implementation of snake ladder therapy in this study is because snake ladder therapy is a fun and not boring activity that can develop communication skills well and are willing to be invited to play by counting numbers and mentioning images and colours.

The research results of Maqdalena [20] show that the application of the method of playing through the game of snakes and ladders is able to improve cognitive development in recognizing the symbol of numbers in group a children. The results of the study Fadilah [21] found that children's self-esteem can be improved through snakeladder educational games by means of children getting used to performing in front of the class doing assignments and showing abilities in front of their peers. The results of the study Firnawati [12] show that associative play (snake ladders) can influence the development of social personal because by playing snakes and ladders the child unconsciously interacts with others and by playing snakes and ladders as parents can see the social personalities that he has in completing a game.

Based on these data according to researchers when children play snakes and ladders of course he played in turns to get a chance so that they can exercise patience and socialization and when playing snakes and ladders children are required to work together. Unconsciously, when playing snakes and ladders, children interact with each other so that the socialization process takes place. Based on previous research, theory and research it can be concluded that given the snake ladder educational game improves social development in preschool children.

\section{CONCLUSION}

The average age of respondents in Sukorejo Wedi Kindergarten are 64.50 months, with sex is distributed equally, 8 males and 8 females. Children social development before given educational game snakes and ladders obtained average value 7. 31 (doubtful) with standard deviation of 0.479 . Children social development after given educational game snakes and ladders obtained average value 9.06 (appropriate) with standard deviation of 0.772 . There is significant influence of educational game snakes and ladders to children social development social before and after intervention ( $\mathrm{p}$-value $=$ $0,000<0,05)$. There is difference on social development score before and after given educational game snakes and ladders which experienced 1.71 increase.

\section{REFERENCES}

[1] M. Siddik, "Hubungan Penggunaan Alat Permainan Edukatif Dengan Perkembangan Anak Usia 3-5 Tahun Di Paud Uswatun Khasanah Sleman Yogyakarta," 2015.

[2] X. Yang, Z. Chen, Z. Wang, and L. Zhu, "The relations between television exposure and executive function in Chinese preschoolers: The moderated role of parental mediation behaviors," Front. Psychol., vol. 8, no. OCT, 2017.

[3] A. I. Nathanson, F. Aladé, M. L. Sharp, E. E. Rasmussen, and K. Christy, "The relation between television exposure and executive function among preschoolers," Dev. Psychol., vol. 50, no. 5, pp. 1497 1506, 2014.

[4] Y. Alghamdi, "Negative Effects of Technology on Business Communications," Hear. Newsp., no. March 2016, pp. 0-13, 2016.

[5] D. A. Wulandari and I. Yuana, "Pengaruh stimulasi alat permainan edukatif terhadap aspek perkembangan anak prasekolah di tk pertiwi boyolali 1," pp. 37-42, 2012.

[6] F. V Ismirayam, A. Trisnasari, and D. E. Kartikasari, "Gambaran Perkembangan Sosial Dan Kemandirian Pada Anak Prasekolah Usia 4-6 Tahun Di Tk Al- Islah Ungaran Barat,” pp. 172-176, 2008.

[7] M. Putri, "Pengaruh Aktivitas Bermain Peran Makro Terhadap Perkembangan Fisik Motorik Kasar Anak Usia 5-6 Tahun Di Tk Adzkia Bandar Lampung (Skripsi) Oleh," 2018.

[8] A. J. O. Whitehouse, D. V. M. Bishop, Q. W. Ang, C. E. Pennell, and S. E. Fisher, "CNTNAP2 variants affect early language development in the general 
[16] Y. Jafri, "Hubungan pemberian stimulasi sosialisasi dengan perkembangan sosialaisasi pada anak prasekolah umur 3-6 tahun di Posyandu kelurahan Pintu Kabun Kota Bukit Tinggi Tahun 2015," Stikes perintis, Bukit Tinggi, 2015.

[17] Muhyidin, N. Rolina, H. Rasyid, and E. Al., Ensiklopedia pendidikan anak usia dini 2. Yogyakarta: Insan Madani, 2014.

[18] Juliani, E. T. MaasaweT, and Daniel, "Pengaruh Model Pembelajaran Kooperatif Teams Games Tournaments (Tgt) Dengan Media Ular Tangga Terhadap Sikap Sosial Siswa Di Sma Negeri 10 Samarinda," Dwijacendekia J. Ris. Pedagog., vol. 1, no. 1, pp. 1-9, 2017.

[19] A. W. Pramesti, L. Andiyanti, and A. Effendi, "Terapi Bermain Ular Tangga Untuk Meningkatkan Perkembangan Bahasa Anak Usia 5-6 Tahun," J. Keperawatan Muhammadiyah, vol. 2, no. 2, 2017.

[13] E. Agustina, "Upaya Meningkatkan Kosakata Melalui Pemanfaatan Media Photo Pada Anak Usia 4-5 Tahun Di Paud Bina Karsa Tanjung Karang Barat Bandar Lampung," 2017.

[14] Adriana, Tumbuh kembang dan terapi bermain pada anak. Jakarta: Salemba Medika, 2011.

[15] I. C. Muloke, "Pengaruh alat permainan edukatif (puzzle) terhadap perkembangan kognitif pada anak usia 5-6 tahun di Desa Linawan Kecamatan Pinolosian Kabupaten Bolaang Mongondow Selatan," Universitas Sam Ratulangi, 2017.
[20] E. Maqdalena and W. A. A, "Meningkatkan Kemampuan Simbol Huruf Melalui Permainan Ular Tangga Pada Anak Usia 5-6 Tahun Di Desa Dukuh Krajan Rt 09 Rw 01 Kelurahan Dukuh Kecamatan Sidomukti Kota Salatiga," ejournal.uksw., vol. 15, no. 2, pp. 2017-2019, 2018.

[21] A. N. Fadilah, "Peningkatan Percaya Diri Melalui Permainan Ular Tangga," J. Pendidik. Anak Usia Dini, vol. I, pp. 81-94, 2016. 